\title{
PEMBANGKITAN ENERGI LISTRIK PADA BATERAI UDARA DENGAN BAHAN KARBON AKTIF DAN ELEKTROLIT AIR LAUT
}

\author{
Benedictus Mardwianta \\ Departemen Teknik Mesin \\ Sekolah Tinggi Teknologi Adisutjipto \\ J1. Majapahit Blok R Adisutjipto Yogyakarta \\ Email : aries2144@yahoo.com
}

\begin{abstract}
Battery technology development has always been developed over the past few years. Batteries in the market today are wet batteries and dry batteries. Wet batteries are widely used for batteries and motorcycles. Dry batteries are widely used in batteries for flashlights, radios, wall clocks and more. The development of the need to create batteries that are environmentally friendly and have considerable energy hence need to look for solution. One solution currently being developed is the creation of air batteries. The working principle of an air battery is to take some of the surrounding air which is in direct contact with the activated carbon cathode so that the air molecules will mix with the electrolyte fluid on the battery and produce voltage and electric current after the cathode is connected to the anode using aluminum foil. This study used a mass of 1250 milligrams active carbon powder and $36 \mathrm{~cm}^{2}$ aluminum foil area. The electrolytic liquid used is sea water. The measurement results obtained using a multimeter tool. Average voltage measurement is 0.781 Volt, average current is $1.043 \mathrm{~mA}$ and electricity generated is $8,148 \mathrm{~mW}$.
\end{abstract}

Keywords: aluminum foil, activated carbon, sea water, air

1. Pendahuluan

Baterai aluminium udara memiliki energi spesifik yang jauh lebih tinggi daripada baterai biasa. Daya tariknya terletak pada sumber zat pengoksidasi. Untuk reaksi pada katoda (elektroda positif) oksigen $\left(\mathrm{O}_{2}\right)$ diambil dari lingkungan bukan dari dalam baterai. Secara teori densitas energi spesifiknya ( $\mathrm{Wh} / \mathrm{kg}$ ) sedikit lebih rendah daripada Li-ion baterai [1]. Banyak logam dapat digunakan sebagai elektroda negatif (anoda) dengan densitas energi yang bervariasi dengan sifat logam karena jumlah elektron yang dipertukarkan, berat molekul logam dan beda potensial elektroda. Semua sel logam-udara memperoleh massa $\left(\mathrm{O}_{2}\right.$ atau $\mathrm{OH}^{-}$) saat dilepaskan [2]. Baterai Zn-udara dan Al-udara sedang banyak dikembangkan karena biaya yang rendah dan kelimpahan material pada kedua logam ini. Korosi anoda logam akan menurunkan masa hidup baterai [3]. Pada tahun 1996, Abraham dan Jiang pertama kali menyampaikan sebuah produk yang dapat diisi ulang yaitu pada baterai $\mathrm{Li}$ $\mathrm{O}_{2}$. Bruce dkk. menunjukkan pada tahun 2006 dilanjutkan penelitian baterai $\mathrm{Li}^{-\mathrm{O}_{2}}$ untuk beberapa siklus. Sebuah alternatif logam-udara yang menjanjikan berupa konsep baterai baru-baru ini dikembangkan dalam istilah baterai silikon-udara primer [4]. Dalam penelitian ini diberikan perhatian khusus pada pembangkitan energi listrik pada baterai udara dengan bahan karbon aktif dan elektrolit yang digunakan adalah air laut. Penggunaan baterai menggunakan aluminium foil, air laut dan karbon aktif dapat menghasilkan baterai sederhana yang cukup kuat untuk menyalakan motor kecil atau menyalakan lampu LED. Aktivitas ini menunjukkan reaksi oksidasi dan reduksi bagian integral dari kimia baterai [5]. Penggunaan oksigen atmosfir sebagai zat pengoksidasi memiliki ekstensi terhadap reaksi redoks lainnya yang terjadi pada korosi, metabolisme, dan pembakaran. Selain itu, partisipasi oksigen sebagai reaktan dalam baterai aluminium-udara dapat digunakan untuk mengenalkan konsep sel bahan bakar dan sumber energi alternatif. Baterai listrik modern pertama terdiri dari rangkaian sel elektrokimia, yang disebut tumpukan volta [6]. Untuk membuat tumpukan volta dengan membangun sel aluminium-udara tambahan. Tumpukan dua 
atau tiga sel aluminium-udara di atas satu sama lain untuk membuat daya baterai lebih kuat. Menghubungkan kabel mengarah ke bagian bawah foil dan menempatkan tumpukan arang diatasnya setelah diberikan pembatas berupa kain kertas. Penekanan ke bawah dengan kuat pada tumpukan baterai adalah untuk mengurangi hambatan internal baterai, namun potongan Aluminium foil tidak saling bersentuhan. Jika foil dari satu sel bersentuhan dengan foil dari sel di atasnya, elektron akan memotong kain kertas dan karbon aktif sehingga tidak lagi menyumbang output daya secara keseluruhan [7]. Secara kuantitatif pengukuran tegangan dan arus listrik dapat dilakukan menggunakan alat bernama multimeter. Tegangan listrik atau beda potensial listrik adalah perbedaan potensial listrik antara dua titik dalam rangkaian listrik. Tegangan listrik merupakan ukuran beda potensial yang mampu membangkitkan medan listrik sehingga menyebabkan timbulnya arus listrik dalam sebuah konduktor listrik [8]. Berdasarkan ukuran perbedaan potensialnya, tegangan listrik memiliki empat tingkatan yaitu tegangan ekstra rendah (extra low Voltage), tegangan rendah (low Voltage), tegangan tinggi (high Voltage) dan tegangan ekstra tinggi (extra high Voltage)[5].Sesuai dengan definisi di atas, bahwa tegangan merupakan perbedaan potensial antara dua titik, yang bisa didefinisikan sebagai jumlah kerja yang diperlukan untuk memindahkan arus dari satu titik ke titik lainnya, maka rumus dasar tegangan antara 2 titik. Baterai mengubah energi kimia menjadi energi listrik. Baterai memiliki dua elektroda yang disebut katoda dan anoda tempat reaksi kimia menghasilkan elektron. Elektroda dihubungkan oleh larutan yang disebut elektrolit supaya ion dapat bergerak menyelesaikan rangkaian listrik. Dalam aktivitas ini, garam menyediakan ion yang bisa bergerak melalui handuk kertas basah dan biaya transfer [9]. Untuk menghasilkan energi listrik, baterai ini bergantung pada oksidasi aluminium pada anoda, yang melepaskan elektron, dan pengurangan oksigen pada katoda, yang menggunakan elektron. Pergerakan elektron melalui sirkuit eksternal menghasilkan arus listrik yang bisa digunakan untuk menyalakan perangkat sederhana.

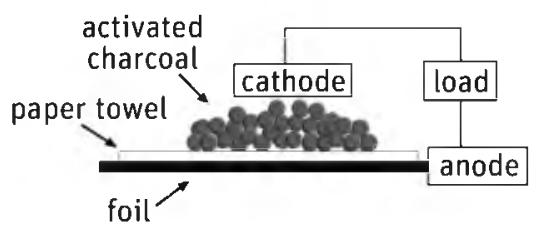

Gambar 1 Baterai dan persamaan untuk setengah dan keseluruhan reaksi

Persamaan untuk setengah dan keseluruhan reaksi:

anode:

$\mathrm{Al}(\mathrm{s})+3 \mathrm{OH}(\mathrm{aq}) \rightarrow \mathrm{Al}(\mathrm{OH})_{3}(\mathrm{~s})+3 e^{-}$

cathode:

$\mathrm{O}_{2}(\mathrm{~g})+2 \mathrm{H}_{2} \mathrm{O}(\mathrm{l})+4 e^{-} \rightarrow 4 \mathrm{OH}(\mathrm{aq})$

overall:

$4 \mathrm{Al}(\mathrm{s})+3 \mathrm{O}_{2}(\mathrm{~g})+6 \mathrm{H}_{2} \mathrm{O}(\mathrm{l}) \rightarrow 4 \mathrm{Al}(\mathrm{OH})_{3}(\mathrm{~s})$

Aluminium foil menyediakan pasokan aluminium yang terjangkau harganya. Karbon aktif yang sebagian besar terbuat dari karbon dapat mengalirkan listrik dan tidak reaktif. Ini disebabkan karbon aktif menyediakan permukaan yang sangat berpori yang terkena oksigen di udara [10]. Satu gram karbon aktif dapat memiliki luas permukaan internal lebih banyak daripada keseluruhan lapangan basket. Luas permukaan ini menyediakan sejumlah besar tempat dimana oksigen dapat terikat dan berpartisipasi dalam reaksi di katoda. Daerah reaksi yang besar ini memungkinkan adanya baterai aluminium-udara sederhana untuk menghasilkan 1 volt $(1 \mathrm{~V})$ dan 100 miliampere $(100 \mathrm{~mA})$. Ini adalah daya yang cukup untuk menjalankan perangkat listrik kecil dan memberikan cara yang aman dan mudah untuk membuat baterai yang mempuyai daya kuat di rumah. Karbon aktif biasa disebut dengan istilah Activated charcoal atau decolourizing carbon. Karbon aktif dapat didefinisikan sebagai bahan padat, berpori, berkarbon yang dibuat dengan karbonisasi dan mengaktifkan zat organik. Bahan baku yang meliputi serbuk gergaji, gambut, lignit, batubara, residu selulosa, tempurung kelapa, kokas minyak bumi, dll, dapat dikarbonisasi dan diaktifkan pada suhu tinggi dengan atau tanpa penambahan garam anorganik dalam aliran gas pengaktifan seperti uap atau karbon 
dioksida. Bentuk karbon aktif berupa serbuk atau butiran, berwarna hitam dan tidak berbau. Karakteristik karbon aktif antara lain Penggunaannya untuk adsorben dan penghilang noda. Tidak larut dalam air dan pelarut organik dan semua pelarut biasa.

2. Metode Penelitian

2.1. Diagram Alir Penelitian

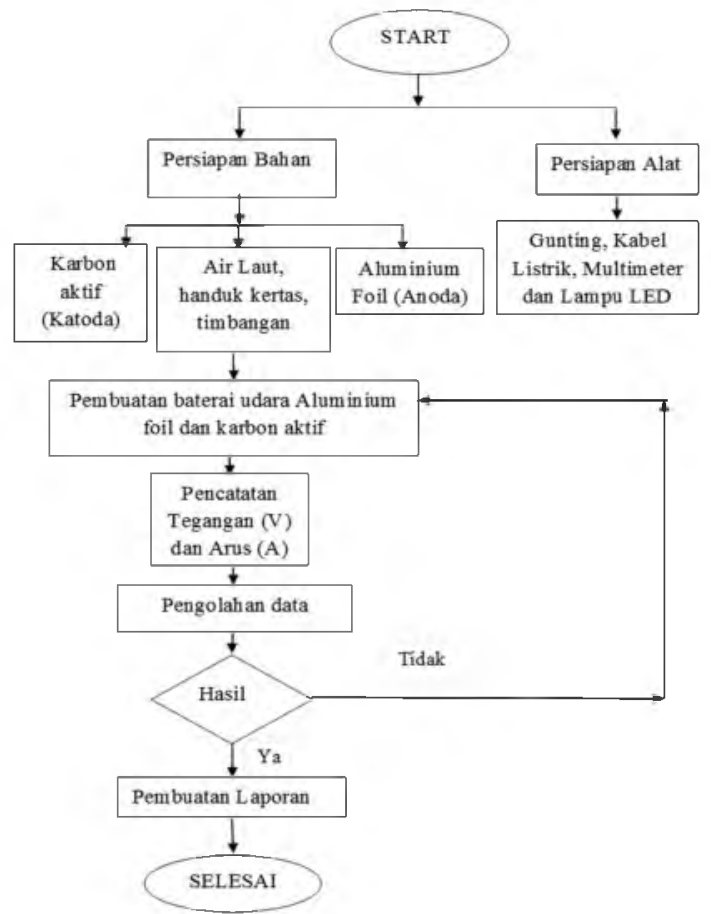

Gambar 2 Diagram alir penelitian

Metode Penelitian pada baterai udara ini meliputi persiapan bahan dan persiapan alat.

\subsection{Persiapan Bahan}

(1) Karbon aktif

Bahan ini berasal dari struktur berpori karbon aktif sehingga memungkinkan untuk menyerap bahan dari fase cair dan gas. Luas permukaan sebagian besar mengandung micropores dengan diameter pori lebih kecil dari $2 \mathrm{~nm}$. Karbon aktif digunakan sebagai katoda.

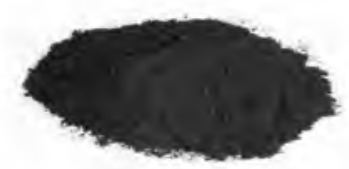

Gambar 3 Karbon aktif
(2) Air laut

Air laut menyediakan ion-ion yang bisa bergerak melalui handuk kertas basah dan berfungsi sebagai cairan elektrolit.

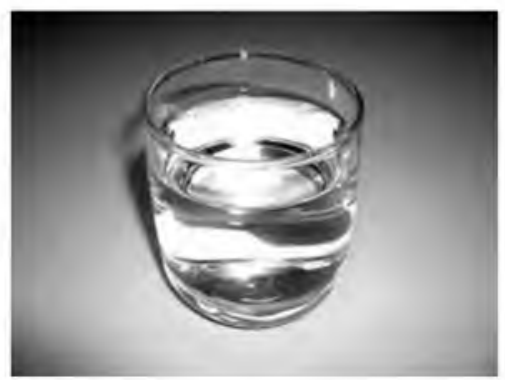

Gambar 4 Air laut

(3) Aluminium Foil

Aluminium foil berfungsi sebagai anoda. Aluminium foil dipotong dengan ukuran $6 \mathrm{~cm} \times 6 \mathrm{~cm}$.

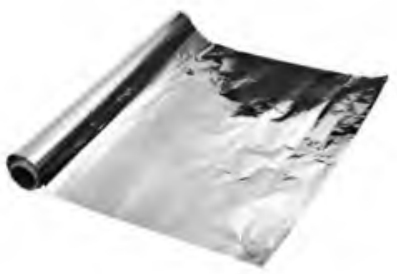

Gambar 5 Aluminium foil

\subsection{Persiapan Alat}

(1) Gunting

Gunting berfungsi untuk memotong Aluminium foil dengan ukuran $6 \mathrm{~cm} \mathrm{x}$ $6 \mathrm{~cm}$.

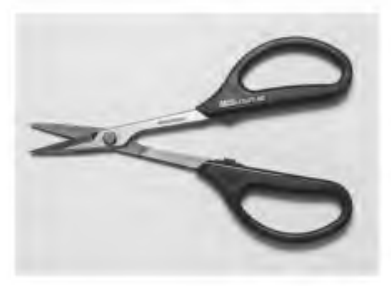

Gambar 6 Gunting

(2) Multimeter

Multimeter berfungsi untuk mengukur tegangan listrik dan arus listrik.Untuk mengukur tegangan listrik dan arus 
listrik pada baterai udara maka multimeter diposisikan pada tanda DC (Direct Current) atau arus searah.

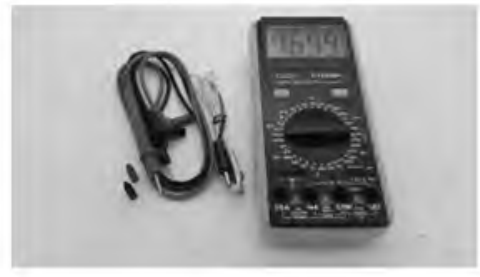

Gambar 7 Multimeter

(3) Kabel listrik

Kabel listrik digunakan sebagai alat penghubung antara katoda dan anoda yang kemudian dihubungkan ke lampu LED

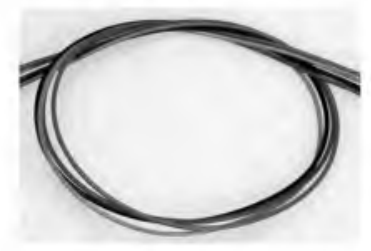

Gambar 8 Kabel listrik

(4) Lampu LED

Lampu LED sebagai alat untuk mendeteksi adanya kecukupan daya listrik yang mengalir pada baterai. Jika lampu LED menyala terang artinya daya listrik yang dihasilkan baterai cukup besar.

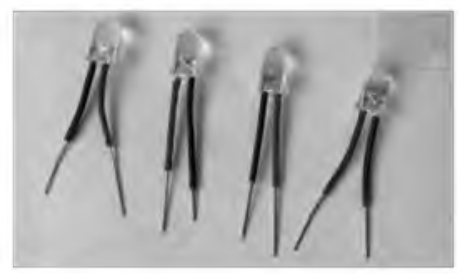

Gambar 9 Lampu LED

\subsection{Pembuatan Baterai}

Dalam pembuatan baterai udara ini digunakan aluminium foil, air laut, dan karbon aktif untuk membangun baterai sederhana yang cukup kuat untuk dapat menyalakan cahaya yang diperoleh dari lampu LED.Memotong aluminium foil dengan ukuran $6 \mathrm{~cm} \times 6 \mathrm{~cm}$. Kemudian menyiapkan air laut yang jernih terbebas dari kotoran berupa lumpur atau zat pengotor yang lain. Langkah selanjutnya adalah menempatkan handuk kertas diatas aluminium foil. Handuk kertas tersebut ditetesi air laut sebagai cairan elektrolit sehingga seluruh area handuk kertas menjadi basah. Kemudian menambahkan karbon aktif diatas handuk kertas tersebut sebanyak 1250 miligram. Untuk mengukur berat karbon aktif menggunakan alat timbangan digital. Setelah itu karbon aktif tersebut kita tetesi dengan air laut supaya karbon aktif mampu mengikat oksigen di udara yang dapat digunakan untuk menghasilkan energ listrik. Posisi handuk kertas berada diantara katoda dan anoda. Katoda berupa serbuk karbon aktif dan anoda berupa aluminium foil. Kemudian langkah selanjutnya adalah memastikan jika karbon aktif tidak menyentuh aluminium foil secara langsung. Jika karbon aktif menyentuh aluminium foil secara langsung maka akan terjadi hubungan arus pendek sehingga daya listrik yang akan dihasilkan tidak dapat menyalakan lampu LED.Kemudian menyiapkan perangkat listrik yang akan digunakan dan menghubungkan katoda dan anoda dengan kabel listrik yang sudah terhubung dengan lampu LED. Melakukan pembuatan sel baterai udara seperti diatas hingga sepuluh kali agar diperoleh daya yang cukup besar untuk menghidupkan lampu LED. Kesepuluh sel baterai udara tersebut dihubungkan secara rangkaian seri sehingga diperoleh tegangan listrik sepuluh kalinya.

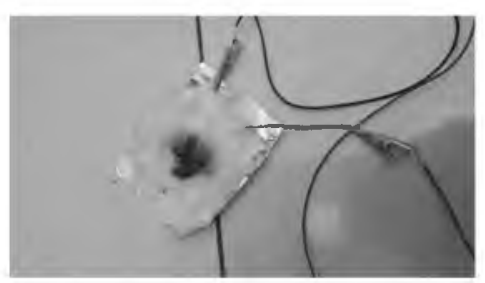

Gambar 10 Sel baterai udara

\subsubsection{Rumus Daya Listrik}

Dalam mengukur daya listrik yang dihasilkan baterai dapat menggunakan persamaan (1).$$
P=V x I
$$$$
\text { (1) }
$$

Dimana :

$\mathrm{P}$ adalah daya listrik $(\mathrm{mW})$
} 
$\mathrm{V}$ adalah tegangan listrik (V)

I adalah arus listrik $(\mathrm{mA})$

\subsubsection{Pencatatan Data}

Melakukan pencatatan pada tiap-tiap komposisi. Pencatatan data yaitu tegangan dan arus listrik menggunakan multimeter digital. Untuk mencatat data tegangan pada multimeter digital diposisikan pada tanda DC (Direct Current) atau arus searah. Untuk mencatat arus listrik diperlukan beban lampu LED dan menghubungkan kabel merah $(+)$ multimeter digital dengan kutub positif lampu LED dan kabel hitam (-) multimeter digital dengan kutub negatif lampu LED.

Tabel 1 Data Tegangan dan Arus

\begin{tabular}{|c|c|c|c|}
\hline Sel Baterai & $\begin{array}{c}\text { Tegangan } \\
\text { (Voli) }\end{array}$ & $\begin{array}{c}\text { Arus } \\
\text { (millAmpere) }\end{array}$ & $\begin{array}{c}\text { Daya } \\
\text { (milWatt) }\end{array}$ \\
\hline Selke-1 & 0.814 & 1.177 & 0.958 \\
\hline Selke-2 & 0.786 & 1.057 & 0.831 \\
\hline Selke-3 & 0.698 & 1.148 & 0.801 \\
\hline Selke-4 & 0.912 & 1.042 & 0.950 \\
\hline Selke-5 & 0.822 & 0.986 & 0.810 \\
\hline Selke-6 & 0.745 & 0.937 & 0.698 \\
\hline Selke-7 & 0.687 & 1.104 & 0.758 \\
\hline Selke-8 & 0.723 & 0.922 & 0.667 \\
\hline Selke-9 & 0.744 & 1.003 & 0.746 \\
\hline Selke-10 & 0.883 & 1.052 & 0.929 \\
\hline Jumlah & $\sum=7.814$ & $X=1.043$ & $\sum=8.148 \mathrm{~mW}$ \\
\hline & & & \\
\hline
\end{tabular}

\subsubsection{Pengolahan Data}

Setelah semua data diperoleh maka data dapat diolah dan dapat diambil kesimpulan pada penelitian ini.

Pada sel ke-1, daya yang diperoleh sebesar :

$$
\begin{aligned}
& \mathrm{P}=\mathrm{V} \times \mathrm{I} \\
& \mathrm{P}=0,814 \text { Volt } \times 1,177 \mathrm{~mA} \\
& \mathrm{P}=0,958 \mathrm{~mW}
\end{aligned}
$$

Pada sel ke-2, daya yang diperoleh sebesar :

$$
\begin{aligned}
& \mathrm{P}=\mathrm{V} \times \mathrm{I} \\
& \mathrm{P}=0,786 \text { Volt } \times 1,057 \mathrm{~mA} \\
& \mathrm{P}=0,831 \mathrm{~mW}
\end{aligned}
$$

Pada sel ke-3, daya yang diperoleh sebesar :

$$
\begin{aligned}
& \mathrm{P}=\mathrm{V} \times \mathrm{I} \\
& \mathrm{P}=0,698 \text { Volt } \times 1,148 \mathrm{~mA} \\
& \mathrm{P}=0,801 \mathrm{~mW}
\end{aligned}
$$

\section{Hasil dan Pembahasan}

Hasil dari pengujian dalam bentuk grafik tegangan, grafik arus dan grafik daya listrik yang dihasilkan baterai udara. Tujuan dibuatnya grafik ini adalah untuk mempermudah pembacaan tegangan, arus dan daya listrik.

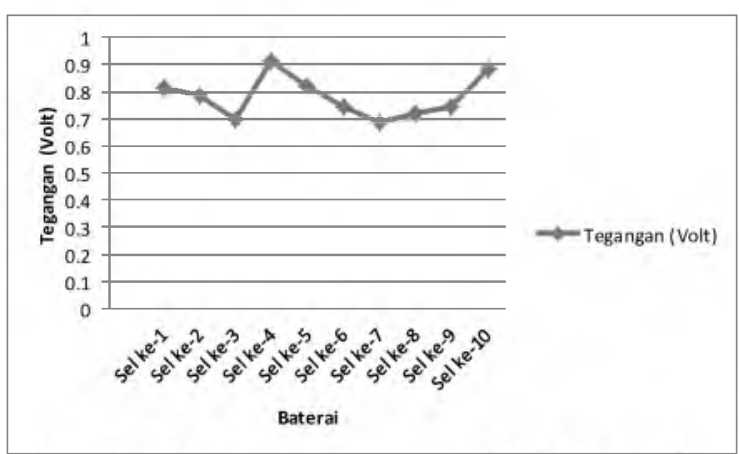

Gambar 11 Grafik Tegangan Pada Baterai

Pengujian tegangan pada baterai dilakukan dengan mengukur setiap sel baterai. Ada sepuluh sel baterai yang diukur menggunakan alat multimeter. Dari grafik pada gambar 11, menunjukkan bahwa tegangan rata-rata dari seluruh sel adalah 0,781 Volt. Tegangan baterai diperoleh karena adanya beda potensial dua terminal di sirkuit. Terminal di aluminium foil dengan potensial yang lebih rendah menuju ke terminal di serbuk karbon aktif dengan potensial yang lebih tinggi. Tegangan listrik ini mampu membangkitkan medan listrik sehingga menyebabkan timbulnya arus listrik dalam sebuah konduktor listrik yang terhubung dengan alat multimeter. Jika pembacaan tegangan di multimeter tidak bekerja setelah beberapa detik maka perlu mengurangi hambatan internal dengan cara meningkatkan area kontak antara ujung kabel (kabel katoda) dengan serbuk karbon aktif dan meningkatkan area kontak antara ujung kabel yang satunya (kabel anoda) dengan aluminium foil. Dalam mengukur DCV, posisi kabel probe warna merah $(+$ /out) diletakkan pada titik positif $(+)$ dari sumber tegangan yang akan diukur, kabel probe warna hitam (-/common) diletakkan pada titik negatif (-).Untuk lebih jelasny dapat dilihat skema dan penempatan selektor batas ukur multimeter untuk mengukur tegangan DC seperti pada gambar berikut. Untuk membaca tegangan DC hasil pengukuran maka perlu dilihat batas ukur yang digunakan yaitu saklar selektor diposisi $2 \mathrm{~V}$ kemudian dapat dibaca pada penunjukan 
digital multimeter sesuai batas ukur yang digunakan.

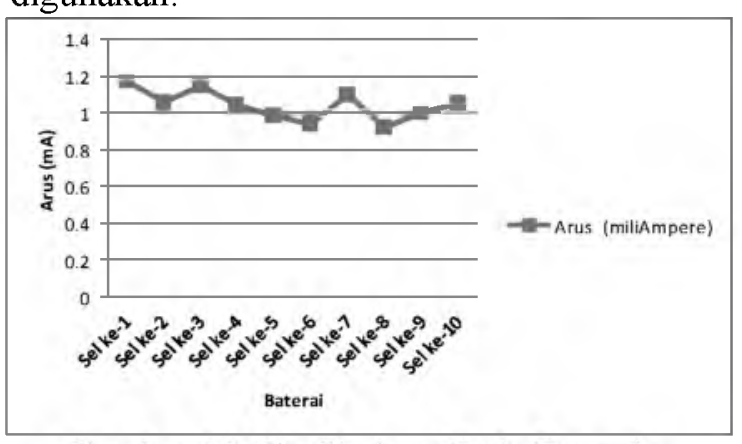

\section{Gambar 12 Grafik Arus Pada Baterai}

Untuk dapat membaca besarnya arus pada multimeter menggunakan cara sebagai berikut yaitu mengatur posisi saklar selektor ke DCA. Kemudian memilih skala sesuai dengan perkiraan arus yang akan diukur yaitu $2 \mathrm{~mA}$. Jika arus yang diukur melebihi skala yang dipilih maka sekering (fuse) dalam multimeter akan putus. Setelah itu menghubungkan probe multimeter ke terminal jalur yang kita putuskan tersebut. Probe merah ke output arus $(+)$ dan Probe Hitam ke input arus dan membaca hasil pengukuran di display multimeter. Kinerja baterai melibatkan transfer elektron melalui suatu media yang bersifat konduktif dari aluminium foil (anoda) ke serbuk karbon aktif (katoda) sehingga menghasilkan arus listrik. Bahan dan luas permukaan aluminium foil (anoda) ke serbuk karbon aktif (katoda) mampu mempengaruhi jumlah beda potensial yang dihasilkan. Setiap bahan elektroda memiliki tingkat potensial elektroda yang berbeda-beda. Jika luas permukaan aluminium foil (anoda) ke serbuk karbon aktif (katoda) diperbesar maka akan semakin banyak elektron yang dapat dioksidasi dibandingkan dengan elektroda dengan luas permukaan yang kecil.

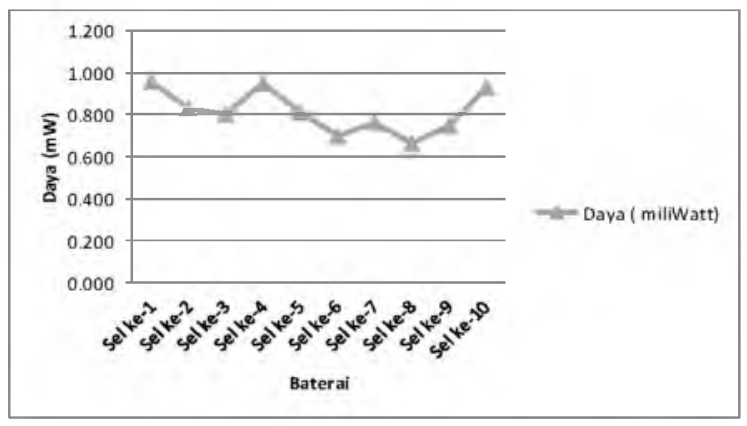

Gambar 13 Grafik Daya Pada Baterai
Daya listrik adalah jumlah energi yang diserap atau dihasilkan dalam sebuah rangkaian. Tegangan listrik akan menghasilkan daya listrik sedangkan beban yang terhubung dengannya akan menyerap daya listrik tersebut. Daya listrik adalah tingkat konsumsi energi dalam sebuah rangkaian listrik. Semakin tinggi nilai arus dan tegangan listrik yang dihasilkan baterai udara maka semakin tinggi pula daya listrik yang dihasilkan. Rumus untuk menghitung daya yaitu tegangan dikalikan dengan arus listrik. Besar total daya listrik yang dihasilkan baterai udara adalah $8.148 \mathrm{~mW}$.

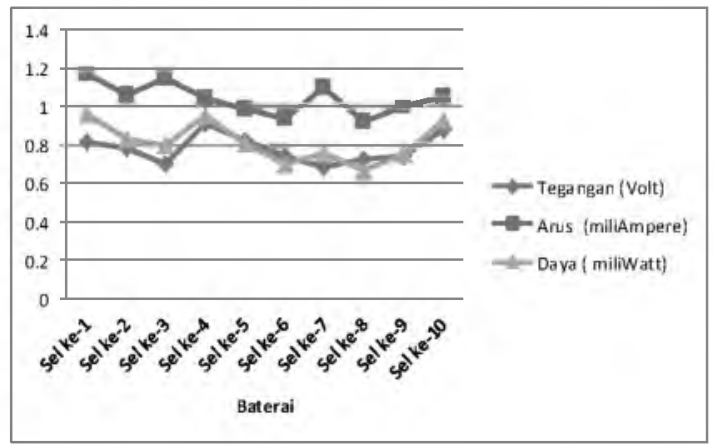

Gambar 14 Grafik Tegangan, Arus dan Daya Pada Baterai

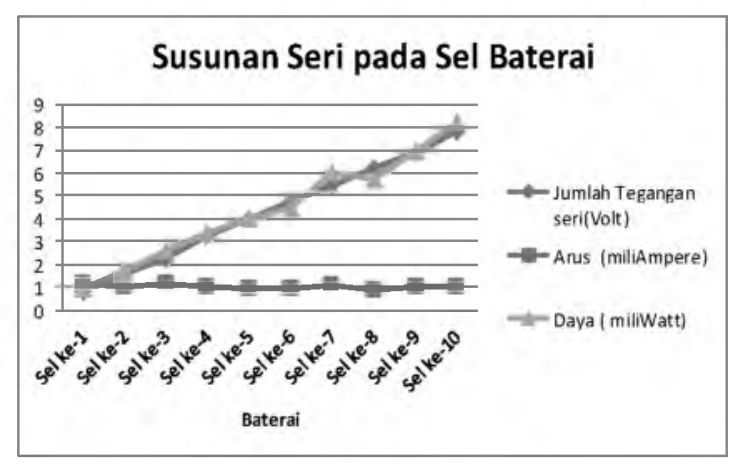

Gambar 15 Grafik Daya Pada Baterai yang disusun seri

Rangkaian seri adalah salah satu model rangkaian listrik yang semua sel-sel baterai dari sel ke-1 sampai sel ke-10 dihubungkan berurutan sehingga setiap bagian dialiri oleh 
arus listrik yang sama. Rangkaian ini disebut juga dengan rangkaian tunggal dan membiarkan listrik mengalir keluar dari baterai udara melalui setiap bagian katoda dan anoda dan kembali lagi ke baterai udara tersebut. Kuat arus yang mengalir selalu sama di setiap titik sepanjang rangkaian. Hambatan yang dirangkai secara seri akan semakin besar nilai hambatannya. Sedangkan lampu yang dirangkai secara seri nyalanya menjadi semakin redup. Apabila satu lampu mati maka lampu yang lain juga akan mati.

\section{Kesimpulan}

Kesimpulan hasil penelitian yang diperoleh, sebagai berikut:

Pengaruh daya yang dihasilkan pada baterai udara sebagai sumber energi listrik alternatif pada baterai udara adalah semakin tinggi nilai arus dan tegangan listrik yang dihasilkan baterai udara maka semakin tinggi pula daya listrik yang dihasilkan. Rumus untuk menghitung daya yaitu tegangan dikalikan dengan arus listrik. Besar total daya listrik yang dihasilkan baterai udara adalah $8.148 \mathrm{~mW}$.

Pengaruh tegangan yang dihasilkan pada baterai udara adalah bahwa tegangan baterai diperoleh karena adanya beda potensial dua terminal di sirkuit. Terminal di aluminium foil dengan potensial yang lebih rendah menuju ke terminal di serbuk karbon aktif dengan potensial yang lebih tinggi. Tegangan listrik ini mampu membangkitkan medan listrik sehingga menyebabkan timbulnya arus listrik dalam sebuah konduktor listrik yang terhubung dengan alat multimeter. Bahan dan luas permukaan aluminium foil (anoda) ke serbuk karbon aktif (katoda) mampu mempengaruhi jumlah beda potensial yang dihasilkan. Jika luas permukaan aluminium foil (anoda) ke serbuk karbon aktif (katoda) diperbesar maka akan semakin banyak elektron yang dapat dioksidasi dibandingkan dengan elektroda dengan luas permukaan yang kecil. Tegangan rata-rata dari seluruh sel adalah 0,781 Volt.

\section{Saran}

Untuk meningkatkan tegangan baterai yaitu dengan menambah luasan aluminium foil sebagai anoda dan menambah massa serbuk karbon aktif. Prinsip kerja baterai udara adalah mengambil sebagian udara sekitar yang kontak langsung dengan katoda karbon aktif sehingga molekul-molekul udara tersebut akan bercampur dengan cairan elektrolit pada baterai dan menghasilkan tegangan dan arus listrik setelah katoda terhubung dengan anoda menggunakan aluminium foil.

\section{Ucapan Terima kasih}

Penulis mengucapkan terima kasih kepada Sekolah Tinggi Teknologi Adisutjipto Yogyakarta yang telah yang telah memberi dukungan financial terhadap penelitian ini. Juga kepada bagian P3M STTA yang telah membantu tugas dosen untuk melaksanakan salah satu Tridharma perguruan tinggi.

\section{DAFTAR PUSTAKA}

[1] Ahmad. 2005. Elektrokimia dan Kinetika Kimia.Bandung: PT. Citra AdityaBakti.

[2] Febri, Aji. 2014.Deret volta. Solo: Universitas Negeri Surakarta

[3] Kartawidjaja dan Abdurrochman. 2008. Pencarian Parameter Bio-batere Berbasis Asam Sitrat $\left(\mathrm{C}_{6} \mathrm{H}_{8} \mathrm{O}_{7}\right)$. Prosiding Seminar Nasional Sains dan Teknologi-II 2008. Universitas Lampung. Lampung

[4] Jeffery, G.H., Bassett, J., Mendham, J., dan Denney, R.C., 1989. Vogel's Textbook of Quantitative Chemical Analysis. New York: John Wiley \& Sons.

[5] Sartono, Muhamad, Vega Noviana, Siti Maemunah dan Nurkamalia Lubis. 2014.Pengaruh Jembatan Garam KCl dan Buah Terhadap Voltase Yang Dihasilkan Sel Galvani. Jurnal Sains dan Teknologi Vol. 1 No. 1

[6] Fessenden dan Fessenden.1986. Kimia Organik Jilid l.Ed Ke-3. Pudjaatmaka AH, penerjemah. Jakarta (ID): Erlangga.

[7] Jankowska H, Swiatkowski A, Choma J. 199l.Active Carbon lst Ed. New York (USA):Ellis Horwood. 
[8] Wold S, Sjostrom M, Eriksson L. 2001.PLSregression: a basic tool of
chemometrics.Chem Intel Lab Syst. 58:114-121 